\title{
Analysis of the Road Risk on the National Road 7 Sector of the Olt River Gorge, between Talmaciu and Calimanesti, for the Years 2011-2018
}

\author{
Lucian Tarnu ${ }^{1}$, and Cristian Deac ${ }^{1, *}$ \\ ${ }^{1}$ Lucian Blaga University of Sibiu, Romania, Department of Industrial Engineering and Management, Emil Cioran str. 4, Sibiu, \\ Romania
}

\begin{abstract}
The study and analysis of the phenomenon of road accidents, that generates risks for the life, physical or psychic integrity and health of humans, but also for material goods, cannot be considered complete without analyzing its dynamics over time and its potential evolution. In this regard, the current paper aims to analyze the general and specific traits of the road risk on the National Road 7, in the Olt River gorge, over a significant time frame, namely 8 years, from 2011 to 2018 . This analysis will also be put into context with the most important road factors - the human factor, the road factor, the vehicle factor and not least with the main causes of the road accidents.
\end{abstract}

\section{Introduction}

Road safety represents the entirety of actions and measures taken for improving the human behaviour, the vehicles and the road infrastructure, that lead to the safe movement of all road traffic participants, by means of reducing the number and severity of accidents [1].

For Romania, road transportation represents the main means to provide the transportation of persons and goods. According to the National Institute of Statistics, road transportation is the transportation means with the highest density of persons, more than three times higher than that of railroad transportation [2]. In Romania there are transported annually on the roads on average 330,000 passengers, representing $78 \%$ of all transported passengers, as well as 230,000 thousand tons of goods, representing $62 \%$ of all goods [3]. Also, while there exist researches on introducing fuels based on renewable energies [4, 5], most cars still used rather old engines.

A modern and sustainable road safety management system for the road infrastructure must include adequate and efficient legal and institutional measures and provisions, as well as techniques and methods that can be used by all institutions responsible for the road infrastructure.

The road risk is an important type of risk for the human health and life, just like any other type of occupational risk (e.g. fire risk or explosion risk, [6]).

In the current paper, the authors have analysed the road risk on a sector with a length of $69 \mathrm{~km}$ of the national road DN7, between Boita and Calimanesti, located in the Olt river gorge and have used the results to draw some conclusions on the situation in this area.

\section{The Management of Road Safety in Romania}

In Romania, the management of road safety is based on the measures and policies included in the National Strategy for Road Safety [7] and in the Action Plan for implementing this strategy, respectively [8]. If all entities involved are participating actively and continuously in applying these measures, the result will be an efficient road safety system.

The management of road safety and the continuous promotion of road safety measures are traditionally the responsibility of the public sector. However, the central and local authorities control all factors that influence the "system" within which all participants in the road traffic operate: the preparation and information of traffic participants, road traffic legislation and regulations, control of the road traffic and applying sanctions, development and improvement of the road infrastructure, legislation for the various categories of vehicles, organisation of the national and local emergency and medical assistance services.

According to data from ETSC [9], in Romania there are recorded annually on average 99 fatalities from road accidents. This is almost double compared to the figure for the whole European Union, which is 50 road accidents fatalities for 1 million inhabitants [9], so a very high rate of fatalities.

\footnotetext{
* Corresponding author: cristian.deac@ulbsibiu.ro
} 
This high fatality rate is not entirely due to the Romanian drivers' behaviour in traffic [1]. Another cause may be found in the type of available roads and specifically in the lack of motorways. The European Commission shows indicates that only a small part of the fatalities (8\% in 2015) occur in accidents on motorways [10], not least because the most dangerous type of accident, the frontal collision, occurs only very rarely on motorways.

The lack of motorways in Romania, coupled with the fact that more than $90 \%$ of the roads have only a single driving track for each travel direction leads to most of the road traffic happening on roads without any physical separation of the travel direction, so frontal collisions are much more common and thus have very grave consequences.

The road maintenance problems (potholes, missing or damaged protection elements), the insufficiently signalled or illuminated repair or maintenance works are further objective causes of the road accidents.

At the end of 2018, in Romania there were almost 9 million motor vehicles [1], of which $78 \%$ were cars. Also, in Romania there are almost 8 million persons with driver licences, representing $40 \%$ of the total population and $45 \%$ of the adult population [1].

On the other hand, there were very few visible investments in the road infrastructure. The road network has recorded only a modest evolution from 1997 to 2017, so that in 2017 there were only 18.2\% more road kilometres in Romania, compared to $1990[1]$.

\section{The Analysed Road Sector}

The authors have chosen for their analysis a stretch of 69 kilometres of the national road DN7, between Boita in the north and Calimanesti in the south.

DN7 is a major road in Romania, connecting the capital Bucharest with the town of Nadlac, at the border with Hungary. It passes through the cities of Pitesti, Ramnicu Vilcea, Sibiu, Sebes, Deva and Arad.

The analysed road sector is of particular importance, firstly because it is part of the main route connecting the cities of Sibiu and Râmnicu Vâlcea, the counties of Sibiu and Vâlcea and on a larger scale the historical provinces of Oltenia and Transylvania and secondly because it is located in the Olt river gorge, between two mountain groups of the Southern Carpathians: the Făgăraș mountains group and the Parâng mountains, an area with limited possibilities for properly developing the road width.

Fig. 1 shows the location of the analysed road sector [11], while figure 2 shows an aerial view of a road section.

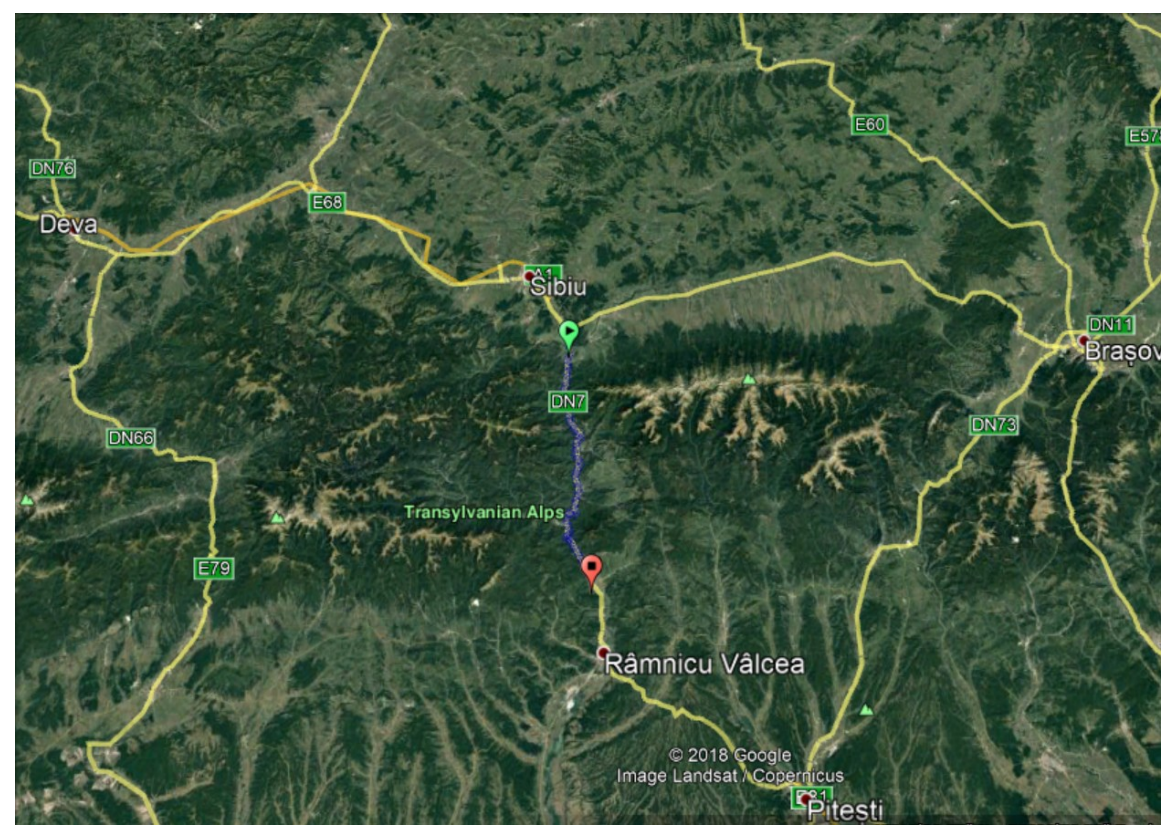

Fig. 1. Map of the analysed road sector [11] 


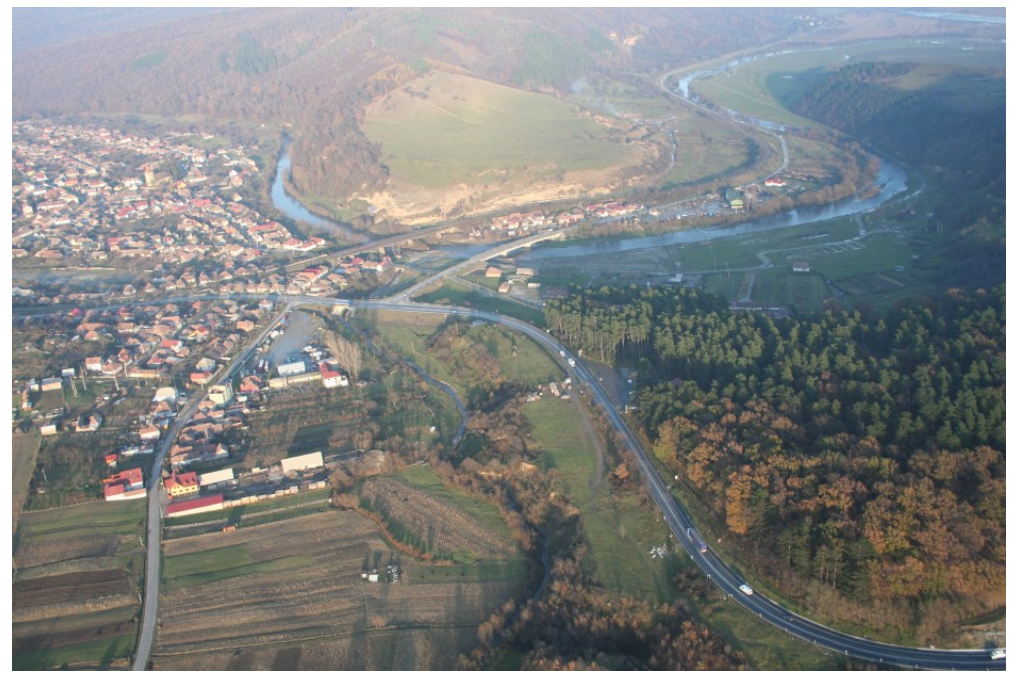

Fig. 2. Aerial view of a part of the analysed road sector

\section{Analysis of the Accidents on the Targeted Road Sector}

In the following, there is presented the statistical situation of road accidents that occurred on the analysed road sector over a period of 8 years, between 2011 and 2018. The data used for this analysis comes from the National Registry of Car Accidents [12].

Figure 3 and table 1 show an analysis of the number of road accidents recorded on the targeted road sector in each of the 8 years.
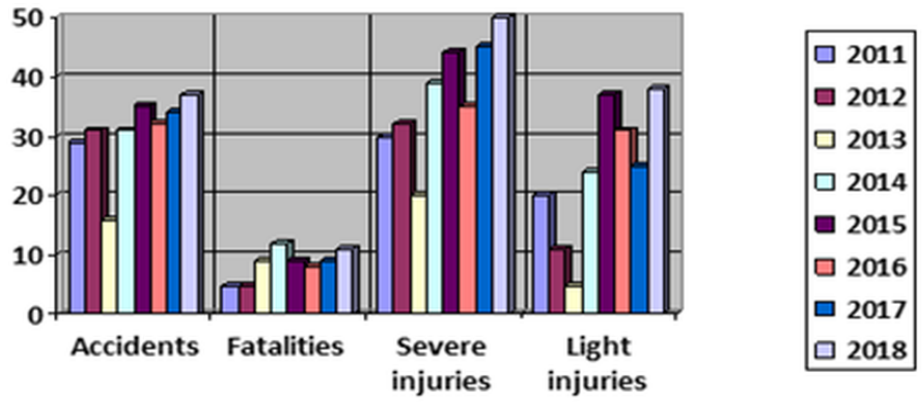

Fig. 3. The variation of the number of accidents and of the various outcomes of accidents between 2011 and 2018 , by year.

Table 1. The variation of the number of accidents and of the various outcomes of accidents between 2011 and 2018 , by year

\begin{tabular}{|l|l|l|l|l|}
\hline Year & Accidents & Fatalities & Severe injuries & Light injuries \\
\hline 2011 & 29 & 5 & 30 & 20 \\
\hline 2012 & 31 & 5 & 32 & 11 \\
\hline 2013 & 16 & 9 & 20 & 5 \\
\hline 2014 & 31 & 12 & 39 & 24 \\
\hline 2015 & 35 & 9 & 44 & 37 \\
\hline 2016 & 32 & 8 & 35 & 31 \\
\hline 2017 & 34 & 9 & 45 & 25 \\
\hline 2018 & 37 & 11 & 50 & 38 \\
\hline TOTAL & 245 & 68 & 295 & 191 \\
\hline
\end{tabular}

From these data it can be concluded that on average, there were 30.45 accidents, the highest number being recorded in 2018, more than double the figure recorded in the year with the lowest number of accidents, 2013.

Figure 4 and table 2 show an analysis of the number of road accidents and their consequences recorded on the targeted road sector between 2011 and 2018, by month. 

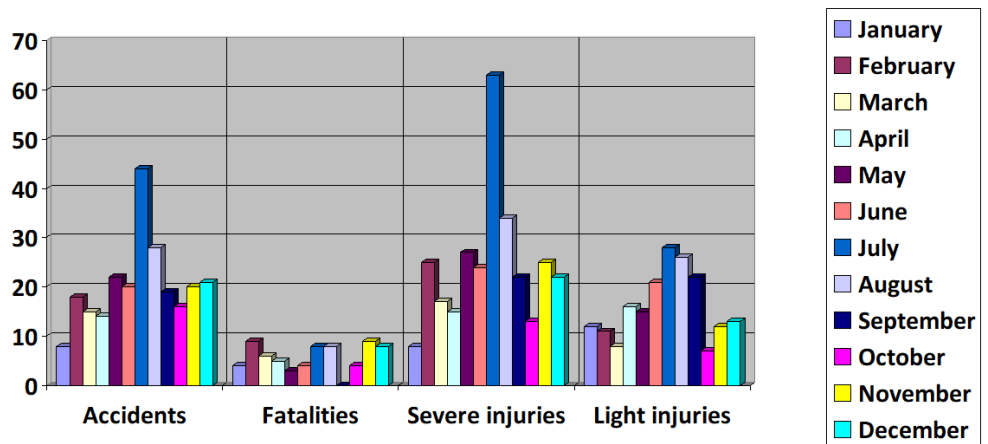

Fig. 4. The variation of the number of accidents and of the various outcomes of accidents between 2011 and 2018, by month of the year

Table 2. The variation of the number of accidents and of the various outcomes of accidents between 2011 and 2018 , by month of the year

\begin{tabular}{|l|l|l|l|l|}
\hline Month & Accidents & Fatalities & Severe injuries & Light injuries \\
\hline January & 8 & 4 & 8 & 12 \\
\hline February & 18 & 9 & 25 & 11 \\
\hline March & 15 & 6 & 17 & 8 \\
\hline April & 14 & 5 & 15 & 16 \\
\hline May & 22 & 3 & 27 & 15 \\
\hline June & 20 & 4 & 24 & 21 \\
\hline July & 44 & 8 & 63 & 28 \\
\hline August & 28 & 8 & 34 & 26 \\
\hline September & 19 & 0 & 22 & 22 \\
\hline October & 16 & 4 & 13 & 7 \\
\hline November & 20 & 9 & 25 & 12 \\
\hline December & 21 & 8 & 22 & 13 \\
\hline TOTAL & 245 & 68 & 295 & 191 \\
\hline
\end{tabular}

It can be noticed that in July, the number of accidents increases significantly compared to other months, this being related to the peak of the periods of leave and summer holidays, when many people either return home from abroad or travel to the seaside. Furthermore, in the rural areas this is a period of intensive agricultural activities and DN7 crosses through several rural areas.

The number of fatalities peaks during the summer months, in July and August, at the year's end, in November and December, but also in February.

Table 3 shows an analysis of the number of road accidents recorded on the targeted road sector in each of the 8 years, by day of the week.

Table 3. The variation of the number of accidents and of the various outcomes of accidents between 2011 and 2018 , by day of the

\begin{tabular}{|l|c|c|c|c|}
\hline $\begin{array}{c}\text { Day of the } \\
\text { week }\end{array}$ & Accidents & Fatalities & Severe injuries & Light injuries \\
\hline Monday & 50 & 9 & 60 & 40 \\
\hline Tuesday & 38 & 8 & 46 & 29 \\
\hline Wednesday & 19 & 3 & 25 & 7 \\
\hline Thursday & 21 & 6 & 25 & 23 \\
\hline Friday & 34 & 16 & 41 & 24 \\
\hline Saturday & 46 & 11 & 47 & 34 \\
\hline Sunday & 37 & 15 & 51 & 34 \\
\hline TOTAL & 245 & 68 & 295 & 191 \\
\hline
\end{tabular}

The weekly dynamics of accidents reveals an increase of up to $25 \%$ of the number of accidents during the weekend and on the first day of the week; these are also the days when the most road fatalities are recorded.

Table 4 indicates the distribution of accidents by the time of day. It can be noticed that the critical time interval is $14.00-22.00$, with a peak around 17.00 . 
Table 4. The variation of the number of accidents between 2011 and 2018, by time of the day

\begin{tabular}{|l|l|l|l|l|}
\hline Time interval & Accidents & Fatalities & Severe injuries & Light injuries \\
\hline $06: 00-14: 00$ & 95 & 25 & 109 & 74 \\
\hline 14:00-22:00 & 107 & 24 & 142 & 76 \\
\hline 22:00-06:00 & 43 & 19 & 44 & 41 \\
\hline
\end{tabular}

\section{Discussion and Conclusions}

This paper has described the dynamics of accidents over various time intervals and also discussed some potential causes for these accidents.

One of the causes is the fact that most of the Olt river gorge road sector of the DN 7 national road uses a single track in each driving direction and even this track has a substandard width. Consequently, it is impossible to overtake slow vehicles and heavy goods transporting vehicles find it very difficult to drive safely.

As has been shown, during the reference period, the fatalities index, defined as the average number of fatalities for each 100 road accidents, has an absolute value of 27 , so that the fatality risk in connection with the road accidents in the Olt river gorge is above the national average value of 22 in the period 2011-2018 [9].

Currently, in Romania there exists no national strategy for researches in the area of road safety and, apart from demonstrative and pilot programs, there is no independent organization for researches related to road safety [1]. This means that in Romania there is no framework for a systematic research on the relevant factors for road safety, road infrastructure, vehicles, human factors, institutional factors etc.

Given the fact that Romania has several research and development structures involved in international research networks, the authors suggest that researches in this area should be unfolded by universities, research institutes or private companies activating in the area of road safety, opening up also the perspective of cooperations in international research projects.

\section{References}

1. Inspectorate-General of the Romanian Police, Buletinul sigurantei rutiere. Raport anual 2017 (Ministerul Afacerilor Interne, București, 2018)

2. National Institute of Statistics, Parcursul pasagerilor in transportul interurban si international de pasageri, pe moduri de transport, TRN136A, http://statistici.insse.ro:8077/tempo-online/\#/pages/tables/insse-table

3. National Institute of Statistics, Marfuri transportate, pe moduri de transport, TRN 137A, Tempo Online, http://statistici.insse.ro:8077/tempo-online/\#/pages/tables/insse-table

4. M. Bibu, M. Dumitru, Sci. Pap. Manag. Ec. Eng. Agri. Rural Dev. 14, 3 (2014)

5. M. Dumitru, M. Stanciu, M. Bibu, Sci. Pap. Agri. Manag, 15, 1 (2013)

6. A.M. Gligor, Sci. Bull. Univ. Ploiesti, LXVII, 4 (2015).

7. Government of Romania, Strategia Nationala de Siguranta Rutiera pentru perioada 2016-2020 (Monitorul Oficial al României, 2016)

8. Government of Romania, Plan de Actiune pentru Implementarea Strategiei Nationale de Siguranta Rutiera pentru perioada 2016-2020 (Monitorul Oficial al României, 2016)

9. ETSC, Ranking EU Progress on Road Safety. 12th Road Safety Performance Index Report (European Transport Safety Council, 2018)

10. ERSO, Annual Accident Report 2018 (European Commission, 2018)

11. Google, Map of Romania (Google Maps, 2018, http://maps.google.com)

12. Inspectorate-General of the Romanian Police, Registrul National al Accidentelor Rutiere (Politia Romana, 2019) 